\begin{tabular}{cc|c}
\hline Tar. Bil. Der. & Journal of Agricultural Sciences \\
& $\begin{array}{c}\text { Dergi web sayfası: } \\
\text { www.agri.ankara.edu.tr/dergi }\end{array}$ & Journal homepage: \\
& www.agri.ankara.edu.tr/journal
\end{tabular}

\title{
Investigation of Melamine Presence in Canned Tuna Fish by Capillary Zone Electrophoresis Method
}

\author{
Buket ER DEMIRHAN ${ }^{a}$, Burak DEMIRHAN", Sezen YARIMKAYA BAŞ ${ }^{\mathrm{b}}$, Gülderen YENTÜR ${ }^{\mathrm{a}}$, Aysel \\ BAYHAN ÖKTEM ${ }^{\mathrm{a}}$ \\ ${ }^{a}$ Gazi University, Faculty of Pharmacy, Department of Food Analysis, 06330 Ankara, TURKEY \\ ${ }^{\boldsymbol{b}}$ Gazi University, Faculty of Pharmacy, Department of Analytical Chemistry, 06330 Ankara, TURKEY
}

\section{ARTICLE INFO}

Research Article

DOI: 10.1501/Tarimbil_0000001333

Corresponding Author: Buket ER DEMIRHAN, E-mail: erbuket@gmail.com, Tel: +90 (312) 2023201

Received: 10 July 2014, Received in Revised Form: 29 December 2014, Accepted: 21 January 2015

\begin{abstract}
Melamine is widely used as a chemical in food industry and may lead to kidney damage. The aim of this study was to determine melamine and $\mathrm{pH}$ value of 80 canned tuna fish samples of four different brands (A, B, C, D) sold in Ankara, Turkey. Quantitative determination of melamine in canned tuna fish samples was carried out by capillary zone electrophoresis with diode array detector (CZE-DAD). The limits of detection and quantitation for melamine were found to be $0.21 \mathrm{mg} \mathrm{kg}^{-1}$ and $0.68 \mathrm{mg} \mathrm{kg}^{-1}$, respectively. The proposed method was successfully applied for the analysis of melamine in canned tuna fish samples by mean recovery with $104.7 \%$ in oily and $107.6 \%$ for light samples. Melamine levels were found as $<0.68 \mathrm{mg} \mathrm{kg}^{-1}$ (LOQ value) in all samples analysed during the period of the study. The mean $\mathrm{pH}$ values $( \pm \mathrm{SE})$ of the samples for the A, B, C and D brands were determined to be $5.89 \pm 0.02,5.86 \pm 0.01,5.83 \pm 0.02$ and $5.82 \pm 0.02$, respectively. As a result, present study shows that the presence of melamine of canned tuna fish obtained during the period of study do not pose a health risk to consumers.

Keywords: Capillary zone electrophoresis; Fish; Melamine

\section{Konserve Ton Balıklarında Melamin Varlığının Kapiler Zon Elektroforez Yöntemi ile Araştırılması}

\section{ESER BİLGÍSİ}

Araştırma Makalesi

Sorumlu Yazar: Buket ER DEMIRHAN, E-posta: erbuket@gmail.com, Tel: +90 (312) 2023201

Geliş Tarihi: 10 Temmuz 2014, Düzeltmelerin Gelişi: 29 Aralık 2014, Kabul: 21 Ocak 2015

\section{ÖZET}

Melamin gıda endüstrisinde yaygın olarak kullanılan bir kimyasal olup, böbrek hasarına neden olabilmektedir. Bu çalışmada Ankara'da satışa sunulan dört farklı markaya (A, B, C, D) ait 80 konserve ton balığı örneğinde melamin ve $\mathrm{pH}$ değerlerinin saptanması amaçlanmıştır. Konserve ton balığı örneklerinde melaminin kantitatif olarak saptanması diyod array dedektörlü kapiler zon elektroforez (CZE-DAD) ile yapılmıştır. Melaminin gözlenebilme ve tayin sınırları 
Sırasıyla $0.21 \mathrm{mg} \mathrm{kg}^{-1}$ ve $0.68 \mathrm{mg} \mathrm{kg}^{-1}$ olarak bulunmuştur. Konserve ton balığ örneklerinde melamin saptanması için önerilen yöntem, yağda muhafaza edilen ton balıkları için \% 104.7 ve light ton balıkları için \% 107.6 ortalama geri kazanımlarla başarılı bir şekilde uygulanmıştır. Çalışma süresince analiz edilen örneklerin tamamında melamin düzeyi tayin sınırının ( $\left.0.68 \mathrm{mg} \mathrm{kg}^{-1}\right)$ altında bulunmuştur. A, B, C ve D markalarına ait örneklerin ortalama pH değerleri $( \pm \mathrm{SH})$ sırasıyla $5.89 \pm 0.02,5.86 \pm 0.01,5.83 \pm 0.02$ ve $5.82 \pm 0.02$ olarak tespit edilmiştir. Sonuç olarak, çalışma süresince temin edilen konserve ton balıklarındaki melamin varlığının tüketiciler açısından sağlık riski oluşturmadığı gözlenmiştir.

Anahtar Kelimeler: Kapiler zon elektroforez; Balık; Melamin

(C) Ankara Üniversitesi Ziraat Fakültesi

\section{Introduction}

Fish is a low-calorie source of protein rich in essential amino acids. Also, it supplies some vitamins and healthy fats (Usydus et al 2009; EPA 2010). It is a very important component of healthy diets of humans, especially pregnant, nursing women and young children (FAO 2005). However, fish may contain contaminants such as melamine that pose human risks (Andersen et al 2008).

Melamine (1,3,5-triazine-2,4,6-triamine, or $\mathrm{C}_{3} \mathrm{H}_{6} \mathrm{~N}_{6}$, CAS number 108-78-1) is a synthetic chemical that can be used in the manufacture of food packaging materials and containers, coming into contact with foods (Ingelfinger 2008; Lu et al 2009; EFSA 2010). Melamine residue may migrate into foodstuffs coming into contact with that material (EFSA 2010). Melamine is not permitted to be used as a feed or food additive. However, it has been illegally added into feed or foodstuffs to artificially deflect their crude protein content (Guo et al 2011). Because melamine is cheap and easily accessible, there is an economic stimulus for its illegal addition (Gossner et al 2009). Melamine has been found in snack foods, dairy products, eggs, confectionary products, fish and some processed foodstuffs (Andersen et al 2008; Ingelfinger 2008; Gossner et al 2009). Melamine is rapidly absorbed from gastrointestinal tract and rapidly excreted in the urine and not metabolized (Lucas 2009). Melamine has various side-effects on health. Oral ingestion affects the digestive tract and cause nausea, vomiting, and diarrhea in animals (Hau et al 2009). Although it has low oral acute toxicity, chronic administration of high concentrations can trigger renal pathology ( $\mathrm{Xu}$ et al 2009). Toxic effect of melamine relates with the rate of exposure (Ingelfinger 2008). The main toxicological effects occur in the excretory organs, and additionally most consistent and dose-related symptoms are stone formation and hyperplasia of the bladder (Gossner et al 2009). Animal studies have reported that it can lead to chronic kidney disease and acute kidney disease. Necrosis of distal tubular cells and mild inflammation are symptoms of melamine-associated acute kidney disease in animals. Larger crystals, interstitial inflammation, and fibrosis occur in chronic toxicity (Bhalla et al 2009).

Many countries have established the criteria of Maximum Residue Limits (MRLs) for melamine in various food products to protect public health and food safety. Therefore, European Union (EU) has reported the Maximum Residue Limit (MRL) of melamine in dairy products and high protein foods as $2.5 \mathrm{mg} \mathrm{kg}^{-1}$ (Guo et al 2011). According to the Codex Alimentarius and Turkish Food Codex (TFC), the levels of melamine should not exceed 1 $\mathrm{mg} \mathrm{kg}^{-1}$ in powdered infant formula and $2.5 \mathrm{mg} \mathrm{kg}^{-1}$ in food (other than infant formula) (FAO 2010; TFC 2012). WHO classified the melamine as a group 3 carcinogenic risk, implying that the evidence of melamine carcinogenicity is inadequate in humans and inadequate or limited in experimental animals (Hau et al 2009). The aim of current study was to investigate the presence of melamine and to determine the $\mathrm{pH}$ values in four different brands of canned tuna fish samples.

\section{Material and Methods}

\subsection{Materials and chemicals}

Eighty canned tuna samples of consistency with different serial numbers were collected from different brands (A, B, C, D) in different 
supermarkets in Ankara, Turkey. These samples were collected before their expiration date without any physical damage.

Methanol $\left(\mathrm{CH}_{3} \mathrm{OH}\right)$, phosphoric acid $\left(\mathrm{H}_{3} \mathrm{PO}_{4}\right)$, hydrochloric acid (HCL) and sodium hydroxide $(\mathrm{NaOH})$ were from Merck Chemical Co. (Darmsdat, Germany). Standard of melamine was purchased from Acros Chemical Co. (Belgium), sodium dihydrogen phosphate $\left(\mathrm{NaH}_{2} \mathrm{PO}_{4}\right)$, trichloroacetic acid $\left(\mathrm{C}_{2} \mathrm{HCl}_{3} \mathrm{O}_{2}, \mathrm{TCA}\right)$, and chloroform $\left(\mathrm{CHCl}_{3}\right)$ were from Merck Chemical (Darmsdat, Germany). Deionized water was used throughout the experiments (Barnstead International, D11901 USA). All the reagents were of analytical grade.

\subsection{CZE analysis of melamine}

The extraction and determination procedures for analysis of melamine were based on the method described by Yan et al (2009). The melamine was analysed by capillary zone electrophoresis method (Agilent HP 3D CE Technologies, USA) using diode array detector. Melamine detection was performed at $206 \mathrm{~nm}$. Detection wavelength was examined and $206 \mathrm{~nm}$ was chosen as the maximum absorbance wavelength for melamine. The capillary utilized had an effective length of $50 \mathrm{~cm}$, and with $75 \mu \mathrm{m}$ of I.D. (Agilent Technologies, USA). For new capillary, pre-conditioning was performed at 96.8 $\mathrm{kPa}$ sequentially with methanol for $10 \mathrm{~min}$, water for $3 \mathrm{~min}, 1.0 \mathrm{M} \mathrm{NaOH}$ for $20 \mathrm{~min}$, water for $3 \mathrm{~min}$, and running buffer $\left(30 \mathrm{mM} \mathrm{NaH}_{2} \mathrm{PO}_{4}\right)$ for $20 \mathrm{~min}$. The capillary was rinsed at $96.8 \mathrm{kPa}$ sequentially with deionized water $(1 \mathrm{~min}), 0.5 \mathrm{M} \mathrm{NaOH}(0.5$ $\mathrm{min})$, deionized water $(1 \mathrm{~min})$, and running buffer ( $3 \mathrm{~min}$ ) at the beginning of each analysis. Sample introduction was facilitated by applying a pressure of $3.4 \mathrm{kPa}$ for $3 \mathrm{~s}$. The separation voltage was $+30 \mathrm{kV}$. Peak area was used for the determination of melamine in canned fish matrixes. The peak migration time for melamine was $2.2 \mathrm{~min}$.

\subsection{Sample preparation of melamine analysis for CZE}

Briefly, 1 g sample was extracted with $9 \mathrm{~mL}$ deionized water, $1 \mathrm{~mL} 10 \%$ trichloroacetic acid and $1 \mathrm{~mL}$ chloroform with homogenizer (Turrax T18 Basic IKA, Germany). Then, sample of canned fish was ultrasonically extracted for $10 \mathrm{~min}$ (Bandelin Sonorex RK156, Germany). The extract was centrifuged at $4000 \mathrm{rpm}$ for 2 min (Jouan MR 1822, France). After centrifuging and filtering, the supernatants were analyzed by CZE-DAD.

Stock solution containing $1000 \mu \mathrm{g} \mathrm{mL}^{-1}$ melamine was prepared by dissolving $10 \mathrm{mg}$ of melamine in $10 \mathrm{ml}$ of $20 \%$ methanol water ${ }^{-1}$. Standard solutions were prepared by diluting the stock solution with $1 \%$ TCA. Calibration curve was obtained, using a series of dilutions containing different levels (0.5-10 $\left.\mu \mathrm{g} \mathrm{mL}^{-1}\right)$ of melamine. The separation buffer was 30 $\mathrm{mM} \mathrm{NaH} \mathrm{PO}_{4}$ ( $\mathrm{pH}$ 3.2). It was prepared by diluting $400 \mathrm{mM} \mathrm{NaH}_{2} \mathrm{PO}_{4}$ and adjusted to $\mathrm{pH}$ value with $0.1 \mathrm{M} \mathrm{H}_{3} \mathrm{PO}_{4}$. All solutions were used after filtration with a $0.45 \mu \mathrm{m}$ filter.

\subsection{Measurement of the $\mathrm{pH}$ values of the fish samples}

The $\mathrm{pH}$ values of the fish samples were determined using a pH meter (Hanna pH 211, Romania) according to Marco et al (2006) and the Turkish Standard Institute (TSI 2010).

\subsection{Statistical analysis}

Oneway ANOVA test was used to test equality of mean differences between $\mathrm{pH}$ values of four brands (Daniel 1991). Significantly different means were separated using Duncan's multiple range test at the $\mathrm{p}<0.05$ level.

\section{Results and Discussion}

Analytical parameters of proposed CZE method for melamine detection are shown in Table 1. The mean recovery was found as $104.7 \%$ in oily canned tuna fish and $107.6 \%$ for light canned tuna fish, respectively. High recovery can be caused by many different reasons.

Recovery more than $100 \%$ indicates that the measured values for a matrix were higher than the nominal value of the spike (Fichorova et al 2008). On the other hand, low level impurities which caused by the sample structure or presence of melamine under the detection limit, increase the 
Table 1- Analytical parameters of the applied CZE method

Çizelge 1-CZE metodunun analitik parametreleri

\begin{tabular}{|c|c|c|c|c|c|}
\hline Analyte & $\begin{array}{l}L O D \\
m g k^{-1}\end{array}$ & $\begin{array}{l}L O Q \\
m g k^{-1}\end{array}$ & $\begin{array}{l}\text { Coefficient of Regression } \\
\text { determination equation } \\
\left(r^{2}\right)\end{array}$ & $\begin{array}{l}\text { Reproducibility } \\
\text { Intraday precision } \\
(n=5, R S D \%)\end{array}$ & $\begin{array}{l}\text { Interday precision } \\
(n=3, R S D \%)\end{array}$ \\
\hline Melamine & 0.21 & 0.68 & $y=2.53 x+0.61$ & $2.07 \%$ & $3.7 \%$ \\
\hline
\end{tabular}

recovery of methods. Similar to our study, other researchers (Yan et al 2009; Wen et al 2010; Gong et al 2013) determined the recovery range of melamine in various foods as $93-104 \%, 94.5-103.7 \%$ and $96-$ $103 \%$, respectively. The limit of detection (LOD) and limit of quantitation (LOQ) were determined as $0.21 \mathrm{mg} \mathrm{kg}^{-1}$ and $0.68 \mathrm{mg} \mathrm{kg}$, respectively. Percentage relative standard deviation (RSD \%) of mean peak area was found $3.7 \%$ for the interday $(n=3)$ precision test and $2.07 \%$ for the intraday $(\mathrm{n}=5)$ precision test. For CZE method of melamine, the calibration graph was linear in a range of $0.5-10$ $\mu \mathrm{g} \mathrm{mL}^{-1}$ with a regression equation, $\mathrm{y}=2.53 \mathrm{x}+0.61$ $\left(r^{2}=0.9995\right)$. All analyses were repeated twice for each sample. The electropherograms of melaminefree and melamine with spiked of sample are shown in Figure 1 and Figure 2, respectively.

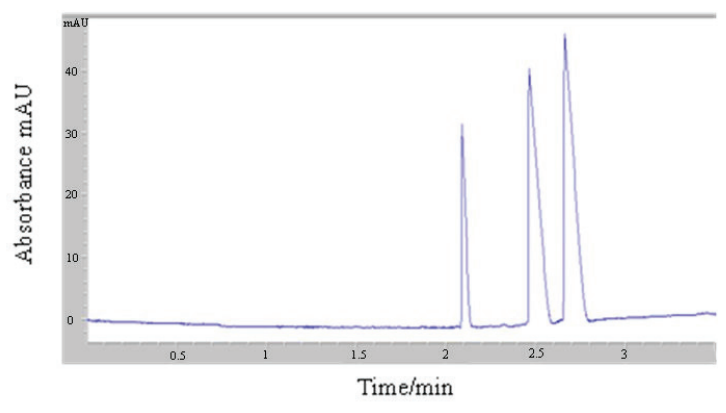

Figure 1- Capillary zone electropherograms of the melamine-free sample under optimum pretreatment conditions and separation conditions (30 mM NaH $\mathrm{PO}_{4}$, pH 3.2, $3.4 \mathrm{kPa}$ pressure for $3 \mathrm{~s}$ and $30 \mathrm{kV}$ separation voltage)

Şekil 1- Melamin içermeyen örneklerin optimum uygulama ve ayırma koşulları (30 $\mathrm{mM} \mathrm{NaH}_{2} \mathrm{PO}_{4}, \mathrm{pH}$ 3.2, $3.4 \mathrm{kPa}$ basınçta 3 saniye ve $30 \mathrm{kV}$ ayırma voltajl) altında kapiler zon elektroferogramları
The presence of melamine in canned tuna fish samples was determined by using CZEDAD. Capillary zone electrophoresis has some advantages according to chromatographic methods such as environmental frendly, analysis time and cost effectiveness for the melamine analysis (Cook et al 2005; Wen et al 2010). The results of the melamine analysis were evaluated according to the Codex Alimentarius and TFC. The melamine levels in the canned tuna fish samples were much lower than the LOQ of $0.68 \mathrm{mg} \mathrm{kg}^{-1}$, thus, it was

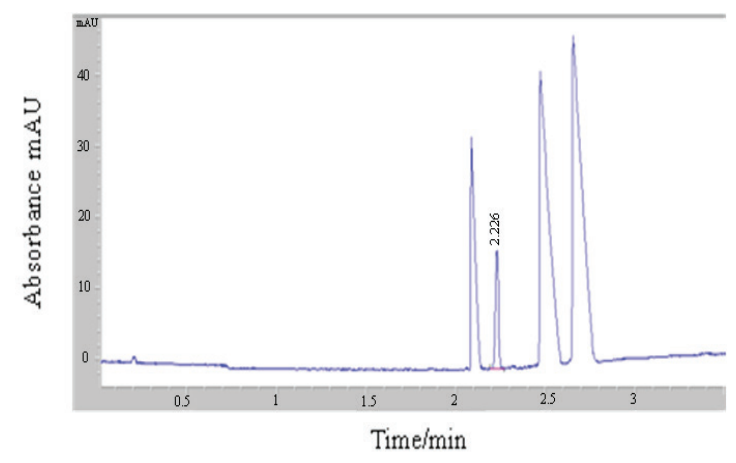

Figure 2- Capillary zone electropherograms of the sample spiked with $50 \mathrm{ppm}$ melamine standart under optimum pretreatment conditions and separation conditions ( $30 \mathrm{mM} \mathrm{NaH} \mathrm{PO}_{4}, \mathrm{pH} 3.2,3.4$ $\mathrm{kPa}$ pressure for $3 \mathrm{~s}$ and $30 \mathrm{kV}$ separation voltage). The peak migration time for melamine was $\mathbf{2 . 2 2 6}$ min. CZE separation of melamine with DAD detection at $206 \mathrm{~nm}$

Şekil 2- 50 ppm melamin standardı eklenen örneklerin optimum uygulama ve ayırma koşulları (30 mM $\mathrm{NaH}_{2} \mathrm{PO}_{4}, \mathrm{pH} 3.2,3.4 \mathrm{kPa}$ basinçta 3 saniye ve $30 \mathrm{kV}$ ayırma voltajı) altında kapiler zon elektroferogramları. Melamin için pik çıkış zamanı 2.226 dakikadır. Melamin kapiler zon elektroforez DAD dedektör ile $206 \mathrm{~nm}$ 'de ayrilmiştır 
much lower than the Codex Alimentarius and TFC limit of $2.5 \mathrm{mg} \mathrm{kg}^{-1}$.

To our knowledge, the presence of melamine in fish and fish products has not been investigated in Turkey. Therefore, this is the first study that related investigation of melamine content in canned tuna fish in Turkey. In the present study, melamine was not detected in canned tuna fish samples. Yan et al (2009) similarly do not report presence of melamine in fish samples in a relevant study. Zhang et al (2014) developed rapid, sensitive and efficient method to determine the melamine in fish, shrimp, clam and winkle by gas chromatography-mass spectrometry in Guangzhou, China. Researchers did not detect the melamine residue in fish and shrimp samples; however they determined that melamine residue of winkle and clam as 0.070 and $0.189 \mathrm{mg}$ $\mathrm{kg}^{-1}$, respectively. These results in fish samples were found to be similar to our research.

The literature available on the occurrence of melamine in fish samples indicates contamination. Melamine monitoring data in Japan indicate levels ranging from 0.02 to $0.55 \mathrm{mg} \mathrm{kg}^{-1}$ in fish (OECD 1998). Andersen et al (2008) concluded that thirty-three samples (31.4\%) of 105 market-ready shrimp, catfish, tilapia, salmon, eel and other types of fish were found to have melamine concentrations above the method detection level $\left(3.2 \mu \mathrm{g} \mathrm{kg}^{-1}\right)$. Ten of these samples $(9.5 \%)$ had a range of melamine concentrations from 51 to $237 \mu \mathrm{g} \mathrm{kg}^{-1}$. In another research, the presence of melamine in fish meal samples was reported as 56\% (Hilts \& Pelletier 2009). Tittlemier et al (2010) determined that melamine concentrations ranged from 0.00409 to $1.10 \mathrm{mg} \mathrm{kg}^{-1}$ in fish and shrimp products in Ottawa, Canada. Deabes and El-Habib (2012) also determined the melamine in infant milk formula, milk powder and basaa fish samples by HPLC method. Researchers did not detect melamine in four samples and found that melamine residues ranged between 7.5$16.6 \mathrm{mg} \mathrm{kg}^{-1}$ in six basaa fish samples.

Contamination of foods with melamine in food chain was occurred by several sources such as environmental contamination of foods or wide spread application of melamine in various industries. In this regard, transitions of melamine to animal products from melamine contaminated animal feeds were also specified (Deabes \& El-Habib 2012).

The mean $\mathrm{pH}$ values $( \pm \mathrm{SE})$ of the samples for the A, B, C and D brands were also determined to be $5.89 \pm 0.02,5.86 \pm 0.01,5.83 \pm 0.02$ and $5.82 \pm 0.02$, respectively. Differences between mean $\mathrm{pH}$ values of brands were statistically significant $(p<0.05)$. The $\mathrm{pH}$ value in canned fish samples was found within value recommended by Turkish Standard Institute (4.0-6.9) (TSI 2010).

\section{Conclusions}

Melamine is a widely used chemical in food industry and may lead to kidney damage. In conclusion, present study shows that the melamine levels of canned tuna fish obtained during the period of study were much lower than the limit of quantitation value. Results may change periodically and contamination of human foods with melamine is important. Therefore, monitoring of melamine residue in edible tissues of fish products is necessary in order to prevent to consume contaminated foods.

\section{References}

Andersen W C, Turnipseed S B, Karbiwnyk C M, Clark S B, Madson M R, Gieseker C M, Miller R A, Rummel N G \& Reimschuessel R (2008). Determination and confirmation of melamine residues in catfish, trout, tilapia, salmon, and shrimp by liquid chromatography with tandem mass spectrometry. Journal of Agricultural and Food Chemistry 56(12): 4340-4347

Bhalla V, Grimm P C, Chertow G M \& Pao A C (2009). Melamine nephrotoxicity: an emerging epidemic in an era of globalization. Kidney International 75: 774-779

Cook HA, Klampfl C W \& Buchberger W (2005). Analysis of melamine resins by capillary zone electrophoresis with electrospray ionization-mass spectrometric detection. Electrophoresis 26: 1576-1583

Daniel NW (1991). Bioistatistic: A foundation for analysis in the health sciences, 5 th ed, New York: Wiley

Deabes M M \& El-Habib R (2012). Determination of melamine in infant milk formula, milk powder and basaa fish samples by HPLC/DAD. Journal of Environmental and Analytical Toxicology 2(4): 1-4

EFSA (2010). Proposed draft maximum levels for melamine in food and feed. European union 
comments for the codex committee on contaminants in food (CCCF). Retrieved in August, 4, 2012 from http://ec.europa.eu/food/fs/ifsi/eupositions/cccf/docs/ cccf_4ddagenda_item5_en.pdf

EPA (2010). Fish consumption advisories, 2010. Retrieved in August, 4, 2012 from http://water.epa. gov/scitech/swguidance/fishshellfish/fishadvisories/ general.cfm\#tabs-2

FAO (2005). Fisheries and aquaculture topics. Fish contaminants. Topics Fact Sheets. Text by Lahsen Ababouch. In: FAO Fisheries and Aquaculture Department, Rome, 2005. Retrieved in August, 4, 2012 from http:/www.fao.org/fishery/topic/14815/en

FAO (2010). Proposed draft maximum levels for melamine in food and feed (N13-2009). Retrieved in July, 5, 2012 from ftp://ftp.fao.org/codex/meetings/ cccf/ cccf4/cf04_05e.pdf

Fichorova R N, Richardson-Harman N, Alfano M, Belec L, Carbonneil C, Chen S, Cosentino L, Curtis K, Dezzutti C S, Donoval B, Doncel G F, Donaghay M, Grivel J C, Guzman E, Hayes M, Herold B, Hillier S, Lackman-Smith C, Landay A, Margolis L, Mayer K H, Pasicznyk J M, Pallansch-Cokonis M, Poli G, Reichelderfer P, Roberts P, Rodriguez I, Saidi H, Sassi R R, Shattock R \& Cummins Jr. J E (2008). Biological and technical variables affecting immunoassay recovery of cytokines from human serum and simulated vaginal fluid: A multicenter study. Analytical Chemistry 80(12): 4741-4751

Gong Y, Wu H \& Fan Z (2013). Water-soluble Eu(III)doped $\mathrm{ZnS}$ quantum dots for the room-temperature phosphorescence detection of melamine in milk products. Analytical Methods 5: 6114-6119

Gossner C M, Schlundt J, Embarek PB, Hird S, Wong DL, Beltran JJO, Teoh KN \& Tritscher A (2009). The melamine incident: implications for international food and feed safety. Environmental Health Perspectives 117(12): 1803-1808

Guo Z, Gai P, Hao T, Wang S, Wei D \& Gan N (2011). Determination of melamine in dairy products by an electrochemiluminescent method combined with solid-phase extraction. Talanta 83(5): 1736-1741

Hau A K, Kwan T H \& Li P K (2009). Melamine toxicity and the kidney. Journal of the American Society of Nephrology 20: 245-250

Hilts C \& Pelletier L (2009). Background paper on occurrence of melamine in foods and feed. Prepared for the WHO Expert Meeting on Toxicological and Health Aspects of Melamine and Cyanuric Acid in collaboration with FAO and supported by Health Canada, 1-4 December 2008. Retrieved in August, 4, 2012 from http://www.who.int/ foodsafety/fs management/Melamine_3.pdf
Ingelfinger J R (2008). Melamine and the global implications of food contamination. The New England Journal of Medicine 359: 2745-2748

Lu J, Xiao J, Yang D J, Wang Z T, Jiang D G, Fang C R \& Yang J (2009). Study on migration of melamine from food packaging materials on markets. Biomedical and Environmental Sciences 22(2): 104-108

Lucas G N (2009). Melamine contamination of food products. Sri Lanka Journal of Child Health 38: 2-3

Marco A, Navarro J L \& Flores M (2006). The influence of nitrite and nitrate on microbial, chemical and sensory parameters of slow dry fermented sausage. Meat Science 73: 660-673

OECD (1998). Screening information dataset for melamine. CAS No. \#108-78-1. Paris, 1998. Retrieved in August, 4, 2012 from http://www.chem. Unep.ch/irptc/sids/ OECDSIDS/108781

TFC (2012). Türk Gıda Kodeksi bulaşanlar yönetmeliğinde değişiklik yapılmasına dair yönetmelik. Resmi Gazete, 19 Aralık 2012.Sayı 28502. Başbakanlık Basımevi, Ankara, Turkey

Tittlemier S A, Lau B P Y, Ménard C, Corrigan C, Sparling M, Gaertner D, Cao X L, Dabeka B \& Hilts C (2010). Baseline levels of melamine in food items sold in Canada. II. Egg, soy, vegetable, fish and shrimp products. Food Additives and Contaminants: Part B: Surveillance 3(3): 140-147

TSI (2010). Turkish Standart Institution. Canned fish, TS 353, Ankara: TSI publications.

Usydus Z, Szlinder-Richert J \& Adamczyk M (2009). Protein quality and amino acid profiles of fish products available in Poland. Food Chemistry 112(1): 139-145

Wen Y, Liu H, Han P, Gao Y, Luan F \& Li X (2010). Determination of melamine in milk powder, milk and fish feed by capillary electrophoresis: a good alternative to HPLC. Journal of the Science of Food and Agriculture 90: 2178-2182

Xu X, Ren Y, Zhu Y, Cai Z, Han J, Huang B \& Zhu Y (2009). Direct determination of melamine in dairy products by gas chromatography/mass spectrometry with coupled column separation. Analytica Chimica Acta 650(1): 39-43

Yan N, Zhou L, Zhu Z \& Chen X (2009). Determination of melamine in dairy products, fish, feed, and fish by capillary zone electrophoresis with diode array detection. Journal of Agricultural and Food Chemistry 57: 807-811

Zhang Y, Ma X \& Fan Y (2014). A rapid and sensitive method for determination of melamine in fish, shrimp, clam, and winkle by gas chromatography-mass spectrometry with microwave-assisted derivatization. Food Analytical Methods 7: 1763-1769 